\title{
Prospective study of fluctuations of lupus anticoagulant activity and anticardiolipin antibody titre in patients with systemic lupus erythematosus
}

\author{
Henk J Out, Marja van Vliet, Philip G de Groot, Ronald H W M Derksen
}

\begin{abstract}
Fluctuations of lupus anticoagulant activity and anticardiolipin antibody titres were studied in 53 patients with systemic lupus erythematosus (SLE). The median study time was 26 months with a median number of 12 samples. Lupus anticoagulant was measured by the kaolin clotting time (KCT) and dilute Russell viper venom time (dRVVT) assays; anticardiolipin antibodies were assayed by an enzyme linked immunosorbent assay (ELISA).

Normal and increased KCTs or dRVVTs were seen during follow up in 13 and 12 patients, respectively. IgG anticardiolipin antibodies changed from negative to positive or positive to negative in 26 patients and IgM anticardiolipin antibodies in 16 patients. Disease activity and treatment with prednisone could account for these fluctuations in the kaolin clotting time (KCT) in 7 of 13 patients and in the dRVVT in 2 of 12 patients. Whole group analysis showed that the KCT, dRVVT, and IgM anticardiolipin antibodies were not associated with disease activity, in contrast with IgG anticardiolipin antibodies. During treatment with prednisone normal KCT and dRVVT results were obtained more easily than normal anticardiolipin antibody levels. It is recommended that lupus patients should not be classified as antiphospholipid antibody positive or negative on the basis of only one sample.
\end{abstract}

The lupus anticoagulant and anticardiolipin antibodies are closely related and are directed against negatively charged phospholipids. ${ }^{1}$ During the last decade their presence has been associated with a variety of clinical symptoms, known as the antiphospholipid syndrome. ${ }^{2}$ The main features of this syndrome are thrombosis, fetal loss, and thrombocytopenia. Most patients with the antiphospholipid syndrome have systemic lupus erythematosus (SLE), ${ }^{3}$ but it has also been described as a primary syndrome in patients without any underlying disease. ${ }^{4}$

Although the pathogenetic potential of antiphospholipid antibodies has not been proven, ${ }^{5}$ patients with the antiphospholipid syndrome are increasingly subject to treatment, especially during pregnancy. ${ }^{6} 7$

To evaluate the clinical significance of these antibodies, information on the natural course of lupus anticoagulant and anticardiolipin antibodies and their reactions during lupus flares or treatment with prednisone is essential. Previously, we reported the fluctuations of lupus anticardiolipin antibodies in a prospective study of 53 patients with SLE. ${ }^{8}$ We showed a significant relation of IgG anticardiolipin antibodies and IgM anticardiolipin antibodies with disease activity in 11 and four patients, respectively. Moreover, it was shown that IgG anticardiolipin antibodies fluctuated in 10 and IgM anticardiolipin antibodies in nine patients with no or mild disease activity during follow up $(n=20)$.

In this study we investigated the incidence of lupus anticoagulant variability in the same cohort of lupus patients in relation to lupus disease activity and treatment with prednisone. The results were compared with the earlier described findings for anticardiolipin antibodies. $^{8}$

\section{Patients and methods}

PATIENTS AND SAMPLES

From September 1984 we have collected blood samples from patients with SLE, diagnosed according to American Rheumatism Association criteria, ${ }^{9}$ at each visit to our outpatient clinic and during hospital admissions. In this study we included all 53 patients from whom at least seven blood samples were available in August 1988. There were 49 women (median age 36 years, range 18-67 years) and four men (median age 33 years, range $30-37$ years). The median duration of follow up was 26 months (range 6-47 months) and a median of 12 samples (range 7-22) was taken. The number of available samples increased with the duration of follow up. In total, 558 samples were evaluated.

Twenty eight women had an obstetric history, including 29 live births in 21 women, and 28 fetal losses in 14 patients (range 1-5 losses per patient). Thirteen patients had had a thrombosis, of whom nine were still receiving oral anticoagulants during the study period. Thirteen patients had a history of thrombocytopenia, of whom 10 also had thrombocytopenic events during the study period. Episodes with thrombosis or fetal loss all took place at least three years before the study period.

Blood samples for the determination of lupus anticoagulant were taken by venepuncture into a 0.1 volume of $3.8 \%$ trisodium citrate. Platelet poor plasma was prepared by centrifuging the blood twice at $4^{\circ} \mathrm{C}$ and $2000 \mathrm{~g}$ for 15 minutes. Blood samples for the preparation of serum for determinations of anticardiolipin antibodies were collected by venepuncture into glass tubes. The blood was allowed to clot at room temperature for two hours and was centrifuged at $2000 \mathrm{~g}$ for 10 minutes to obtain serum samples. All plasma and serum samples were stored at $-70^{\circ} \mathrm{C}$ before determination. All samples from 
individual patients were tested for lupus anticoagulant or anticardiolipin antibodies on the same day.

\section{DISEASE ACTIVITY}

Disease activity and treatment with prednisone were recorded at each sample point. Disease activity was assessed with a previously published scoring system consisting of typical clinical and laboratory features of SLE and classified as inactive (score 0-1), mild (score 2-3), moderate (score 4-5), or severe (score $\geqslant 6$ ). ${ }^{8}$ The index has been validated by Ter Borg et al by comparing its score with the score on a $10 \mathrm{~cm}$ visual analogue scale assessed by clinicians experienced in the management of lupus patients $(r=0.67, \mathrm{p}<0.001) .^{10}$

\section{LUPUS ANTICOAGULANT}

The presence of lupus anticoagulant was assessed by two clotting assays.

\section{Kaolin clotting time}

This was determined using the method of Exner et al. ${ }^{11}$ Test and control plasma were mixed at $37^{\circ} \mathrm{C}$ at different ratios $(0,50$, and $100 \%$ test plasma) in plastic tubes. Immediately after mixing, $0.1 \mathrm{ml}$ of the mixture was incubated with $0.05 \mathrm{ml} \mathrm{kaolin}$ ( $20 \mathrm{mg} / \mathrm{ml}$ Michaelis acetate/ veronal buffer solution) for three minutes at $37^{\circ} \mathrm{C}$. Calcium chloride $(25 \mathrm{mmol} / \mathrm{l}, 0.1 \mathrm{ml})$ was added and the time taken to form clots was accurately measured in duplicate with an automated coagulometer (KC10; Amelung, Lieme, Germany). Results were expressed as a KCT index according to the formula described by Rosner et $a l^{12}$ :

$$
\frac{(\text { KCT 1:1 mixture })-(\text { KCT control plasma })}{(\text { KCT test plasma })} \times 100
$$

In healthy controls $(n=42)$ an index of 5 (12) (mean (2 SD)) was calculated. Values above 17 indicated the presence of lupus anticoagulant.

\section{Dilute Russell viper venom time assay}

The dRVVT assay was performed as described previously. ${ }^{13}$ Briefly, Russell viper venom (Burroughs Welcome, Raleigh, NC, USA) was reconstituted as instructed by the manufacturer and further diluted 1:200 in TRIS buffered saline $(0.15 \mathrm{~mol} / \mathrm{l}$ sodium chloride, $0.02 \mathrm{~mol} / 1$ TRIS, pH 7.5) and stored on ice. The phospholipid reagent Thrombofax (Ortho Diagnostics Systems, Raritan, NJ, USA) was diluted 1:8 in TRIS buffered saline. The dRVVT assay was performed by incubating $0.1 \mathrm{ml}$ plasma, $0.1 \mathrm{ml}$ diluted Russell viper venom, and $0.1 \mathrm{ml}$ diluted phospholipid for 30 seconds at $37^{\circ} \mathrm{C}$, after which $0.1 \mathrm{ml} 25 \mathrm{mmol} / 1$ calcium chloride was added and the clotting time recorded with the coagulometer. Mean (SD) values of 42 normal controls tested on four different occasions were $29 \cdot 3(2 \cdot 2), 38 \cdot 7(3 \cdot 2), 39 \cdot 8(3 \cdot 6)$, and $41 \cdot 0(3 \cdot 6)$ s. The mean standard deviation was $3 \cdot 2 \mathrm{~s}$. Normal values on each test day were established by the mean dRVVT of three different normal donors plus two standard deviations $(6 \cdot 4 \mathrm{~s})$. The dRVVT was considered positive when prolonged clotting times were not corrected by the addition of an equal volume of normal plasma.

\section{ENZYME LINKED IMMUNOSORBENT ASSAY FOR ANTICARDIOLIPIN ANTIBODIES}

Anticardiolipin antibodies (IgG and IgM) were measured by an enzyme linked immunosorbent assay as described by Loizou et $a^{14}$ and modified by Derksen et al. ${ }^{15}$ Positive results were taken as a value in units more than two standard deviations greater than the value obtained with a pooled control serum derived from 71 healthy volunteers. All results were expressed as the ratio of patient anticardiolipin antibody levels to that of the results plus two standard deviations of pooled normal serum assayed on the same ELISA plate (anticardiolipin antibody index) to make comparisons of anticardiolipin antibody assays performed on different days and to perform whole group analysis. An index of less than 1 represented negative anticardiolipin antibody levels and an index of 1 or more was considered positive.

Table 1 Follow up of 17 patients with fluctuating KCT assay results $(n=13)$ or fluctuating $d R V V T$ assay results, or both (n=12). Only significant $p$ values are given

\begin{tabular}{|c|c|c|c|c|c|c|c|c|c|}
\hline \multirow[t]{2}{*}{$\begin{array}{l}\text { Patient } \\
\text { No }\end{array}$} & \multirow{2}{*}{$\begin{array}{l}\text { No of } \\
\text { KCT assay } \\
\text { results } \\
\text { positive/negative }\end{array}$} & \multirow{2}{*}{$\begin{array}{l}\text { No of } \\
\text { dRVTT assay } \\
\text { results } \\
\text { positive/negative }\end{array}$} & \multirow{2}{*}{$\begin{array}{l}\text { Duration of } \\
\text { follow up } \\
\text { (months) }\end{array}$} & \multirow{2}{*}{$\begin{array}{l}\text { Range of } \\
\text { disease } \\
\text { activity } \\
\text { score }\end{array}$} & \multirow{2}{*}{$\begin{array}{l}\text { Range of } \\
\text { prednisone } \\
\text { dose (mg) }\end{array}$} & \multicolumn{2}{|c|}{$\begin{array}{l}\text { Correlation coefficient } \\
\text { of disease activity score with }\end{array}$} & \multicolumn{2}{|c|}{$\begin{array}{l}\text { Correlation coefficient } \\
\text { of prednisone dose with }\end{array}$} \\
\hline & & & & & & $K C T$ & $d R V V T$ & $K C T$ & $d R V V T$ \\
\hline $\begin{array}{r}1 \\
2 \\
3 \\
4 \\
5 \\
6 \\
7 \\
8 \\
9 \\
10 \\
11 \\
12 \\
13 \\
14 \\
15 \\
16 \\
17\end{array}$ & $\begin{array}{l}0 / 21 \\
1 / 8 \\
12 / 4 \\
15 / 0 \\
12 / 3 \\
11 / 4 \\
11 / 2 \\
9 / 5 \\
3 / 6 \\
18 / 1 \\
5 / 4 \\
12 / 3 \\
0 / 16 \\
12 / 2 \\
3 / 14 \\
5 / 3 \\
0 / 7\end{array}$ & $\begin{array}{l}2 / 19 \\
0 / 9 \\
15 / 1 \\
10 / 5 \\
2 / 13 \\
4 / 11 \\
11 / 2 \\
11 / 3 \\
0 / 9 \\
19 / 0 \\
6 / 3 \\
1 / 14 \\
1 / 15 \\
11 / 3 \\
0 / 17 \\
0 / 8 \\
2 / 5\end{array}$ & $\begin{array}{r}19 \\
24 \\
22 \\
41 \\
37 \\
43 \\
39 \\
43 \\
6 \\
35 \\
19 \\
20 \\
25 \\
18 \\
15 \\
16 \\
19\end{array}$ & $\begin{array}{l}1-7 \\
0-11 \\
0-1 \\
0-13 \\
0-5 \\
0-2 \\
0-4 \\
0-9 \\
1-10 \\
0-6 \\
1-4 \\
2-14 \\
0-5 \\
1-6 \\
2-11 \\
0-3 \\
0-2\end{array}$ & $\begin{array}{l}15-30 \\
\overline{-} \\
0-75 \\
5-10 \\
0-40 \\
0-40 \\
0-60 \\
25-60 \\
\overline{20-65} \\
0-60 \\
5-25 \\
5-60 \\
10-40 \\
5-40 \\
-\end{array}$ & $\begin{array}{c}0.79^{*} \\
-0.25 \\
0.32 \\
0.14 \\
-0.43 \\
-0.43 \\
0.86 \dagger \\
0.37 \\
0.59 \\
0.52^{*} \\
0.28 \\
-0.10 \\
0.51\end{array}$ & $\begin{array}{c}-0.11 \\
0.85 \ddagger \\
-0.32 \\
-0.20 \\
0.53\end{array}$ & $\begin{array}{l}-0.40 \\
-0.85 \ddagger \\
-0.94 \ddagger \\
-0.27 \\
-0.19 \\
-0.17 \\
-0.10 \\
-0.68 \dagger \\
-0.49 \\
-0.80^{*}\end{array}$ & $\begin{array}{c}-0.38 \\
0.42 \\
-0.25 \\
-0.56^{*} \\
-0.31\end{array}$ \\
\hline
\end{tabular}




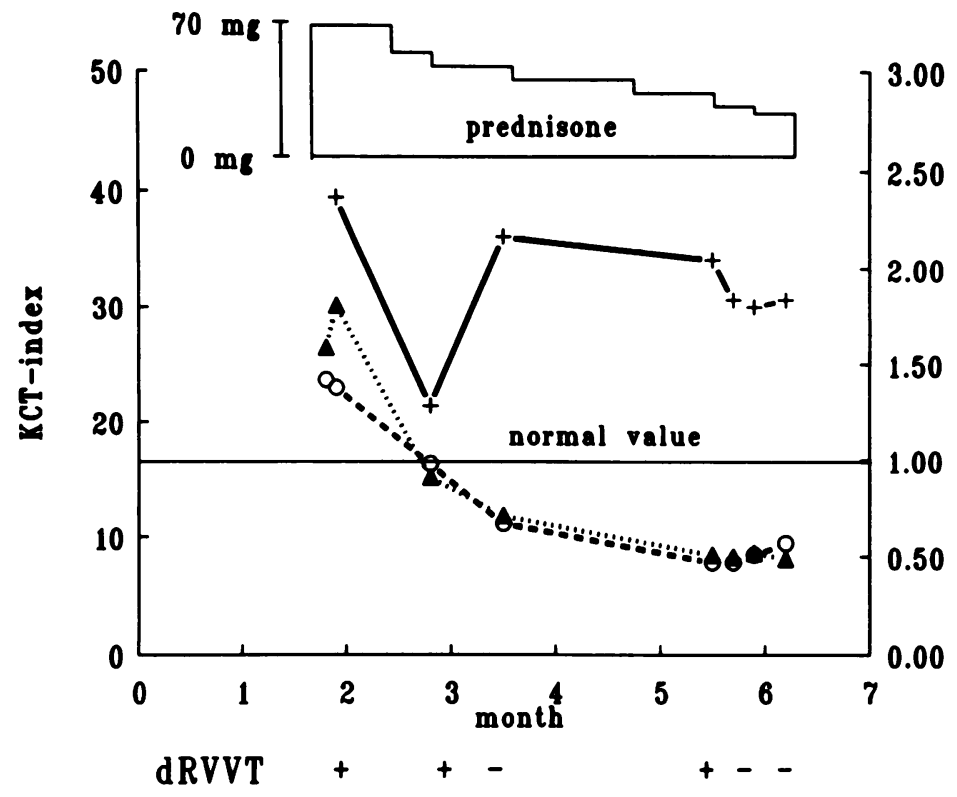

Figure 1 Follow up of lupus anticoagulant and anticardiolipin antibodies (ACA) in patient 4 during a five month period. During treatment with high doses of prednisone, anticardiolipin antibody levels (IgG ACA ... $\triangle$..., IgM ACA clotting time $(K C T-+-)$ remained positive.

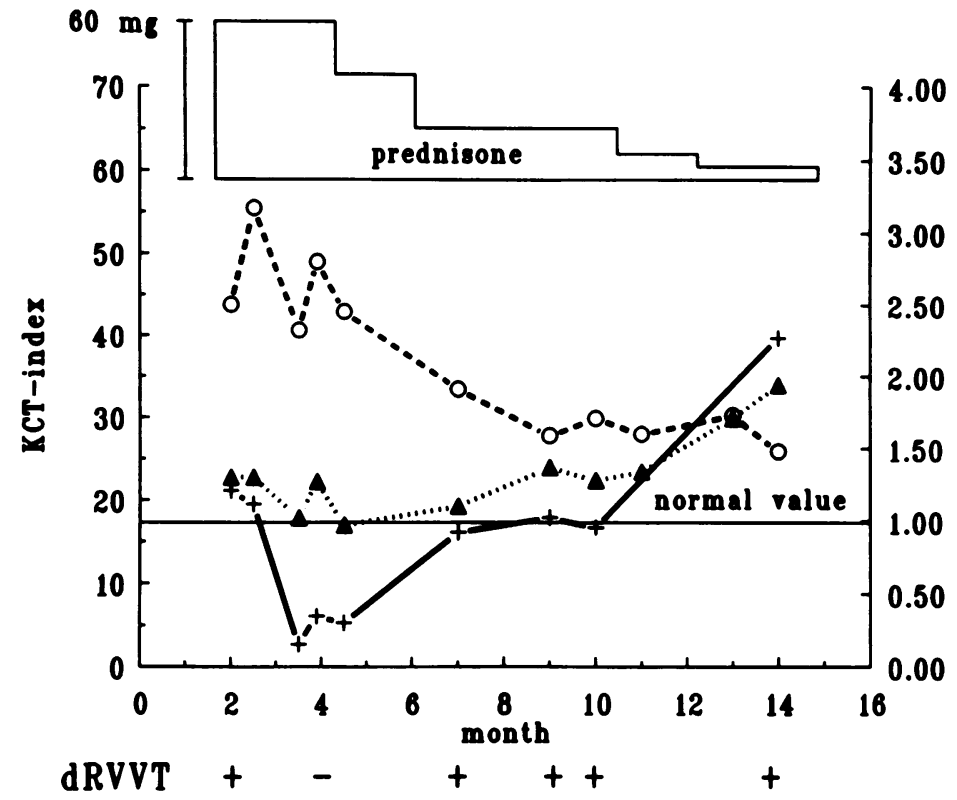

Figure 2 One year follow up of patient 8. The anticardiolipin antibody levels were always positive during treatment with prednisone. The kaolin clotting time $(K C T-+-)$ and dilute Russell viper venom time (dRVVT) initially became negative, but returned to positive values after a further decrease of the prednisone dose. Note that anticardiolipin IgM levels also decrease (IgG ACA ... ...., IgM ACA -O-), but only after several months.

Table 2 Interrelations between kaolin clotting time (KCT), dilute Russell viper venom time (dRVVT), anticardiolipin antibodies (IgG ACA, IgM ACA), and disease activity score by $\chi^{2}$ analysis (degrees of freedom) in 318 blood samples obtained from 53 patients with systemic lupus erythematosus

\begin{tabular}{|c|c|c|c|c|}
\hline & $d R V V T$ & $I g G A C A$ & $\operatorname{IgM} A C A$ & $\begin{array}{l}\text { Disease activity } \\
\text { score }\end{array}$ \\
\hline $\begin{array}{l}\text { KCT } \\
\text { dRVVT } \\
\text { IgG ACA } \\
\text { IgM ACA }\end{array}$ & $\begin{array}{l}\chi^{2}=206(1) \\
p<0.001\end{array}$ & $\begin{array}{l}\chi^{2}=49.0 \\
p<0.001 \\
\chi^{2}=58 \cdot 1 \\
p<0.001\end{array}$ & $\begin{array}{l}\chi^{2}=24 \cdot 7(1) \\
p<0.001 \\
\chi^{2}=29 \cdot 9 \\
p<0.001 \\
\chi^{2}=19 \cdot 1 \\
p<0.001\end{array}$ & $\begin{array}{l}\chi^{2}=5.67(3) \\
\mathbf{p}=0.129 \\
\chi^{2}=3.86(3) \\
\mathbf{p}=0.277 \\
\chi^{2}=7.98(3) \\
\mathbf{p}=0.046 \\
\chi^{2}=0.53(3) \\
\mathbf{p}=0.911\end{array}$ \\
\hline
\end{tabular}

\section{STATISTICS}

Pearson's correlation coefficients, $\chi^{2}$ tests were used where appropriate. No discrimination between different normal KCT or dRVVT assay results was made when Pearson's correlation coefficients were calculated. When the $\chi^{2}$ analysis was performed, all antiphospholipid antibody assays were regarded as dichotomous variables (either positive or negative). Fluctuations of lupus anticoagulant and anticardiolipin antibodies were defined as shifts from positive to negative results or vice versa.

Results

FOLLOW UP

Of 53 patients, 11 always gave positive results in the KCT assay, 10 in the dRVVT assay, 10 in the IgG ELISA, and 11 in the IgM ELISA. Twenty nine patients always gave negative results in the KCT assay, 31 in the dRVVT assay, 17 in the IgG ELISA, and 26 in the IgM ELISA. Fluctuations were seen in 13 patients with the KCT assay, 12 patients with the dRVVT assay, in 26 patients with the IgG ELISA, and in 16 with the IgM ELISA. Fluctuations were not accompanied by a change in the platelet count or thrombosis.

VARIABILITY IN LUPUS ANTICOAGULANT ACTIVITY Seventeen patients showed fluctuations in lupus anticoagulant activity during follow up (table 1 , figs 1-3), including five patients with fluctuating KCT assay results, four patients with fluctuating dRVVT assay results, and eight patients with fluctuating results for both the KCT and dRVVT assays. Of 13 patients with fluctuating KCT assay results, three patients showed a significant relation of the KCT with disease activity and four patients with treatment with prednisone, as assessed by Pearson's correlation coefficient. In six patients the fluctuations in KCT assay results were not significantly associated with disease activity nor treatment with prednisone. One patient (patient 15) showed a decrease in positive KCT assay results to normal values one month before a severe disease activity score (score 11).

Of 12 patients with positive and negative dRVVT assay results during follow up, an association with disease activity was significant in one patient (fig 3 ). In one patient a significant association of treatment with prednisone with the dRVVT assay results could be shown.

WHOLE GROUP ANALYSIS

The interrelations between KCT, dRVVT, IgG anticardiolipin antibodies, IgM anticardiolipin antibodies and disease activity were examined for the whole group using six random samples $(n=318)$ from each patient (table 2). Significant relations were found between the results of all antiphospholipid antibody assays $\left(\chi^{2}, \mathrm{p}<0.001\right)$. IgG anticardiolipin antibodies were significantly associated with disease activity $(p=0.046)$, whereas the results of the KCT, dRVVT, and IgM anticardiolipin assays were not. 
EFFECT OF PREDNISONE ON LUPUS

\section{ANTICOAGULANT AND ANTICARDIOLIPIN}

ANTIBODIES

Potential discordant effects of prednisone on lupus anticoagulant and anticardiolipin antibodies were studied in all patients with increased KCT or dRVVT assay results and increased

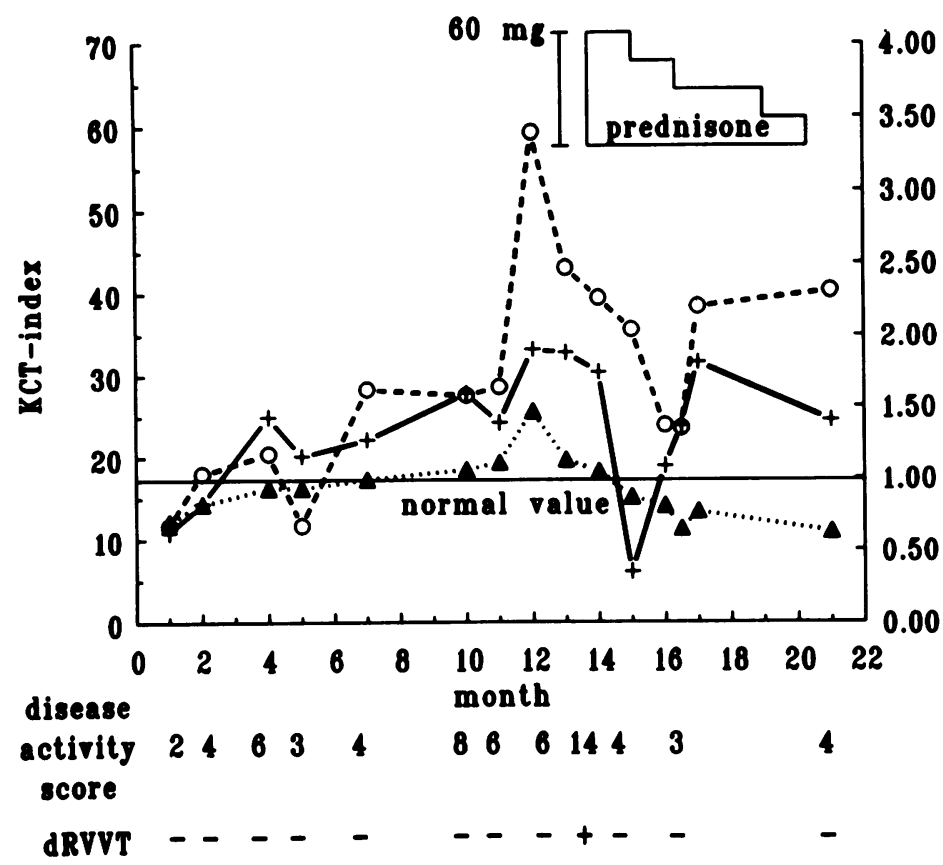

Figure 3 Follow up of antiphospholipid antibodies in patient 12. The kaolin clotting time (KCT - + -) and anticardiolipin antibodies (IgG ACA ......, IgM ACA -.-O--) assay results gradually increase in parallel with disease activity. One month before severe lupus exacerbation (score 14), the highest values of anticardiolipin antibodies were seen. Dilute Russell viper venom time ( $d R V V T$ ) assay results are positive at the time of exacerbation. After treatment with high doses of prednisone the KCT, dRVVT, and IgG $A C A$ assay results returm to normal values. The IgM ACA titre decreases, but remains raised relative to normal values.

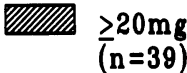
$\underset{(n=39)}{\geq 20 \mathrm{mg}}$ $<20 \mathrm{mg}$ $(\mathrm{n}=82)$

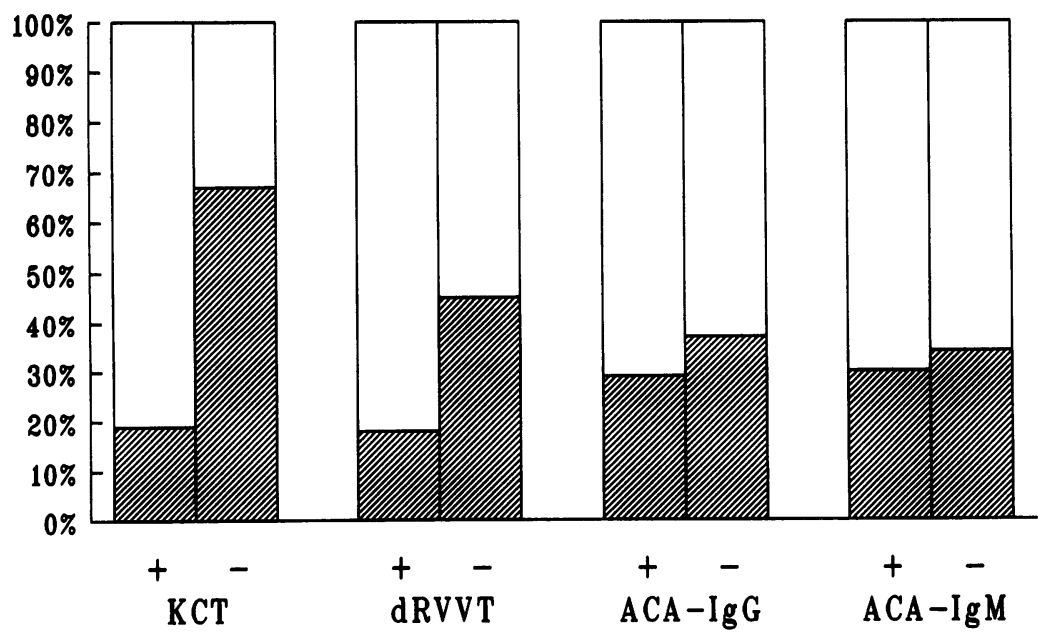

Figure 4 Proportion of samples with positive and negative assay results related to treatment with low ( $<20 \mathrm{mg}$ ) or high doses $(\geqslant 20 \mathrm{mg}$ ) of prednisone at the sampling time. All patients with positive kaolin clotting time (KCT) or dilute Russell viper venom time (dRVVT) and positive IgG or IgM anticardiolipin antibody (ACA) results with at least four samples obtained during treatment with high doses of prednisone are included (eight patients, 121 samples). The number of positive samples during treatment with high doses of prednisone in the KCT assay was $17(19 \%)$, in the dRVVT assay 10 (18\%), in the IgG ACA ELISA 20 (29\%), and in the IgM ACA ELISA $16(30 \%)$. The dose of prednisone and the assay result were significantly associated $\left(\chi^{2}\right)$ for the KCT $(p<0.001)$, and dRVVT $(p=0.002)$ assays, but not for the IgGACA and IgM ACA ELISA. levels of IgG or IgM anticardiolipin antibodies, from whom at least four samples were obtained during treatment with $20 \mathrm{mg}$ or more of prednisone $(n=8$, patients $4,6,7,8,12,14,15$, 16). When all available samples of these patients $(n=121)$, including samples obtained during treatment with less than $20 \mathrm{mg}$ prednisone were considered together, the proportion of positive samples during treatment with high doses of prednisone ( $\geqslant 20 \mathrm{mg}$ ) was $19 \%$ for the KCT assay, $18 \%$ for the dRVVT assay, $29 \%$ for IgG anticardiolipin antibodies, and $30 \%$ for IgM anticardiolipin antibodies (fig 4). $\chi^{2}$ Analysis testing the independence of assay results (positive or negative) against prednisone dose ( $\geqslant 20$ and $<20 \mathrm{mg}$ ) was rejected for the KCT assay $(p<0.001)$ and the dRVVT assay $(p=0.002)$, but not for the IgG and IgM anticardiolipin antibody assays.

\section{Discussion}

This study shows that lupus anticoagulant activity in patients with SLE can fluctuate during the course of the disease. These fluctuations are less common than shifts in the presence of anticardiolipin antibodies. Positive and negative lupus anticoagulant assays in the same patient were seen in $12(23 \%)$ patients assessed by the dRVVT assay and in 13 (25\%) patients by the KCT assay. In comparison, fluctuations of IgG and IgM anticardiolipin antibodies from positive to negative or vice versa occurred in $26(49 \%)$ and $16(30 \%)$ of patients, respectively. The relatively low occurrence of lupus anticoagulant fluctuations explained the more consistent relation of lupus anticoagulant with the antiphospholipid syndrome compared with anticardiolipin antibodies (data not shown).

An association of disease activity with fluctuations in the antiphospholipid antibody titre has been described by Shergy et al. ${ }^{16}$ Kalunian et $a l^{17}$ could not show such an association. We found disease activity or treatment with prednisone to be associated with fluctuations of the KCT assay results in 7 of $13(54 \%)$ patients, and of the dRVVT assay results in 2 of $12(17 \%)$ patients. In the remaining six and ten patients, respectively, no apparent cause for the fluctuations of lupus anticoagulant activity during follow up could be given. However, we determined the relations between lupus anticoagulant and disease activity or treatment with prednisone by the correlation coefficient, which only detects linear relations. It cannot be ruled out that these associations are non-linear in some patients. In one patient (patient 15) a decrease in KCT assay results to normal levels preceded an exacerbation of lupus, which has also been described for antiDNA antibodies. ${ }^{10}$ Also, it can be assumed that prednisone shows its influence only after a prolonged period of treatment. In addition, fluctuations of lupus anticoagulant may also reflect the natural course of lupus anticoagulant or intercurrent viral infections. 18

In this same cohort of lupus patients we previously showed that IgG anticardiolipin antibodies correlated with disease activity in 11 patients (23\%) and IgM anticardiolipin anti- 
bodies in four patients $(9 \%){ }^{\gamma}$ Therefore, of all the antiphospholipid antibodies IgG anticardiolipin antibody seems to be the most correlated with lupus activity; this could also be shown in the whole group analysis using six random samples from each patient. The KCT, dRVVT, and IgM anticardiolipin antibodies failed to show an association with disease activity, in contrast with IgG anticardiolipin antibodies. This association may be due to the fact that the ELISA for IgG anticardiolipin antibodies, rather than clotting assays such as the KCT or dRVVT assays, in part detects antibodies produced as a result of a general polyclonal B cell activation during lupus flares.

Whole group analysis also showed significant relations between all antiphospholipid antibody assays. The KCT and dRVVT assays were most significantly associated $\left(\chi^{2}=206\right.$, one degree of freedom, $\mathrm{p}<0.001)$. We have chosen these two lupus anticoagulant assays because they are easily performed using automated coagulometers and are known to be very sensitive and specific.

This study also shows that the proportion of positive KCT and dRVVT assay results on samples obtained during treatment with more than $20 \mathrm{mg}$ of prednisone is lower than the proportion of positive ELISA results for anticardiolipin antibodies, suggesting that during high dose prednisone treatment lupus anticoagulant is more responsive to steroid treatment than anticardiolipin antibodies (fig 4). This agrees with an earlier observation that we made on four (additional) patients. ${ }^{19}$ In contrast, the KCT assay results of one patient (patient 4, fig 1) remained positive, despite treatment with high dose prednisone, whereas the anticardiolipin antibody levels decreased to normal values, showing the heterogeneity of antiphospholipid antibodies. The discordant effects of treatment with prednisone of lupus anticoagulant and anticardiolipin antibodies must be taken into account when lupus anticoagulant activity or anticardiolipin antibody titres are used to determine the dose of prednisone-for example during pregnancy. Anticardiolipin antibody titres may decrease during treatment with high doses of prednisone, but this effect may only be noted after several months (fig 2).

In conclusion, we have shown that lupus anticoagulant activity is a more constant parameter than anticardiolipin antibodies in patients with lupus. However, fluctuations do occur, sometimes in parallel with treatment with prednisone or with disease activity. Therefore, before classifying patients with lupus as antiphospholipid antibody positive or negative, it should be realised that such a classification may change with time. Monitoring the dose of prednisone or lupus disease activity using antiphospholipid antibodies should be performed carefully, as individual responses may differ, reflecting the intrinsic heterogeneity of these antibodies.

HJO is supported by a grant from the Praeventiefonds (28-1511).

1 Harris E N, Asherson R A, Hughes G R V. Antiphospholıpıd antibodies-autoantibodies with a difference. Ann Rev Med 1988; 39: 261-71

2 Hughes G R V, Asherson R A, Khamashta M A. Antiphospholipid syndrome: linking many specialties. Ann Rheum Dis 1989; 48: 355-6.

3 Derksen R H W M, Kater L. Lupus anticoagulant: revival of an old phenomenon. Clin Exp Rheumatol 1985; 3: 349-57.

4 Asherson R A, Khamashta M A, Ordi-Ros J, et al. The "primary" antiphospholipid syndrome: major clinical and "primary" antiphospholipid syndrome: major clinical and

5 Alarcon-Segovia D. Pathogenetic potential of antiphospholipid antibodies. $\mathcal{F}$ Rheumatol 1988; 15: 890-3.

6 Lubbe W F, Butler W S, Palmer S J, Liggins G C. Fetal survival after prednisone suppression of maternal lupusanticoagulant. Lancet 1983; i: 1361-3.

7 Branch D W, Scott J R, Kochenour N K, Hershgold E. Obstetric complications associated with the lupus anticoagulant. N Engl F Med 1985; 313: 1322-6.

8 Out H J, Groot de PhG, Hasselaar P, Vliet van M, Derksen $R \mathbf{H}$ W M. Fluctuations of anticardiolipin antibody levels in patients with systemic lupus erythematosus: a prospective study. Ann Rheum Dis 1989; 48: 1023-8.

9 Tan E M, Cohen A S, Fries J F, et al. The 1982 revised criteria for the classification of systemic lupus erythematosus. Arthritis Rheum 1982; 25: 1271-7.

10 Ter Borg E J, Horst G, Hummel E J, Limburg P C, Kallenberg C G M. Measurements of increases in antidouble-stranded DNA antibody levels as a predictor of disease exacerbation in systemic lupus erythematosus: a long-term, prospective study. Arthritis Rheum 1990; 33: $634-43$.

11 Exner T, Richard K A, Kronenberg H. A sensitive test demonstrating lupus anticoagulant and its behavioural patterns. Br 5 Haematol 1978; 54: 709-12.

12 Rosner E, Pauzner R, Lusky A, Modan M, Many A. Detection and quantitative evaluation of lupus circulating anticoagulant activity. Thromb Haemost 1987; 57: 144-7.

13 Thiagarajan P, Pengo V, Shapiro S S. The use of the dilute Russell viper venom time for the diagnosis of lupus anticoagulants. Blood 1986; 68: 869-74.

14 Loizou S, McCrea J D, Rudge A C, Reynolds R, Boyle C C, Harris E N. Measurement of anti-cardiolipin antibodies by an enzyme-linked immunosorbent assay (ELISA): standardization and quantitation of results. Clin Exp Immunol 1985; 62: 738-45.

15 Derksen R HW M, Hasselaar P, Blokzijl L, Gmelig Meyling F H J, Groot de PhG. Coagulation screen is more specific than the anticardiolipin antibody ELISA in defining a thrombotic subset of lupus patients. Ann Rheum Dis 1988; 47: $364-71$.

16 Shergy W J, Kredich D W, Pisetsky D S. The relationship of anticardiolipin antibodies to disease manifestations in pediatric systemic lupus erythematosus. $\mathcal{f}$ Rheumatol 1988; 15: 1389-94.

17 Kalunian K C, Peter J B, Middlekauff H R, et al. Clinical significance of a single test for anti-cardiolipin antibodies in patients with systemic lupus erythematosus. Am $\mathcal{J}$ Med patients with syste

18 Vaarala O, Palosko T, Kleemola M, Aho K. Anticardiolipin response in acute infections. Clin Immunol Immunopathol 1986; 41: 8-15

19 Derksen R H W M, Biesma D, Bouma B N, Gmelig Meyling F H J, Kater L. Discordant effects of prednisone on anticardiolipin antibodies and the lupus anticoagulant. Arthritis Rheum 1986; 29: 1295-6. 